\title{
The Social Policies and Programs of the State from the Perspective of Multidimensional Poverty in the Puno Region
}

\author{
Juan Inquilla Mamani \\ National University of the Altiplano, Puno, Peru \\ Email: inquilla@hotmail.com
}

How to cite this paper: Mamani, J.I. (2018) The Social Policies and Programs of the State from the Perspective of Multidimensional Poverty in the Puno Region. Open Access Library Journal, 5: e4474. https://doi.org/10.4236/oalib.1104474

Received: March 6, 2018

Accepted: April 24, 2018

Published: April 28, 2018

Copyright (c) 2018 by author and Open Access Library Inc.

This work is licensed under the Creative Commons Attribution International License (CC BY 4.0).

http://creativecommons.org/licenses/by/4.0/

\section{(c) (i) Open Access}

\begin{abstract}
This research focuses on evaluating coverage results, targeting mechanisms, coherence of objectives, goals and actions developed by social programs, as well as the social impact expressed in the reduction of extreme poverty and the improvement of the quality of life of the target population in the Puno region. The method used is Differences in Differences; this design allows us to incorporate some degree of pre-existing differences between the treatment group and the control group, controlling for observable characteristics of the latter. The results found at the level of the region as a result of the implementation of the evaluated programs show a positive impact on the components evaluated: Targeting system (leaks and subcodes); achievement and fulfillment of program objectives and goals; transfer and delivery of economic subsidies and improvement of their welfare; food attention to the target population (Qaliwarma and Vaso de Leche), which shows the importance of social programs in favor of the poorest population and the extreme poor. Finally, we analyze whether the effect of receiving the monetary transfer on the monthly income in the household, which is directly related to the improvement of the users' welfare in both the "Together" and "Pension 65 " programs, however, these effects are heterogeneous when presenting components and the reduction of multidimensional poverty in the Puno region.
\end{abstract}

\section{Subject Areas}

Economics, Sociology

\section{Keywords}

Impact Assessment, Coverage, Targeting, Transfer and Economic Subsidy and Social Welfare 


\section{Introduction}

The evaluation of public management in the current context goes from being a technical exercise to being a tool for the makers of public policies; this technical-political exercise has at least two important meanings: 1) it covers the three levels of social action of the state, national, regional and local and 2) generates management capacity for decision making between the different levels of government, thus creating coherence in public management. Therefore, today we understand the evaluation of public policies as a tool for the modernization of the state, rather than a simple technique of public management.

This new context allows us to highlight aspects to be taken into account in the evaluation processes of public policies. First, greater emphasis is placed on the results produced by social policies and programs, rather than the inputs or the means to achieve them (effectiveness and impact). Secondly, the point of view of the "users" of social programs emphasizes on the quality of services, rather than the policy operators. Thirdly, greater responsibility and citizen participation are demanded in the accountability of performance and results of the implementation of social programs in the country.

In this context, the impact evaluation of social programs (Juntos, Pension 65, QaliWarma and Vaso de Leche) understood as tools of state intervention, has become a mandatory requirement for public policy makers and operators, as well as associated with the achievement of the country's objectives and the improvement of society. Within the types of evaluation (ex-ante, process, final or ex-post), the impact evaluation is one of the most important and, the least applied in the country. Indeed, with the impact evaluation it is possible to identify the effects caused by the intervention of the program to the users, that is, whether the activities carried out or the goods and services delivered have produced the expected results and changes in a given time.

In addition, the results of the impact evaluation carried out on social programs (Pension 65, Juntos, QaliWarma and Vaso de Leche), show relatively positive results in the fulfillment of the initially proposed objectives, especially the programs that grant an economic subsidy. Conditional grants have a significant impact on improving household income (Pension 65 and Together); likewise, programs (QaliWarma and Vaso de leche) have a greater impact on the food and health component (see Table 1, Table 3 and Table 5). Therefore, the results of the impact evaluation allow us to suggest the necessary modifications to face the problems detected and take advantage of the strengths of each program under study, contributing with empirical evidence for the achievement of its objectives. In general terms, impact evaluation contributes to the efficient use of resources and high effectiveness in meeting objectives, by offering information to improve decision-making processes. The results of the impact evaluation of social programs are fundamental elements to make future decisions and to optimize the policies, strategies and allocation of economic resources of the State.

However, achieving the objectives of impact evaluation implies seeing in a 
comprehensive, valid and reliable way, according to modern scientific and technological development; as mentioned in the part of the theoretical framework. Impact evaluation involves the systematic application of social research procedures to test new intervention ideas, evaluate the conception, design, implementation and effectiveness of social intervention programs, thus providing effective feedback. In this sense, impact evaluation becomes an indispensable technical and political tool for modern public management, however, its complexity and scarce bibliographical stock in Spanish speech impedes its application, both in academic spaces and in the institutional public administration. To these limitations are added many erroneous beliefs about this method, distorting its nature and usefulness.

In effect, the study is structured as follows: The first part presents the summary and the introduction of the topic; in the second part, theoretical aspects of the impact evaluation of public policies are discussed; in the third part the study method and materials are described; in the fourth part of analyze the results of the investigation; and finally the conclusions and bibliography used for the investigation are presented.

\section{Theoretical Framework}

Studies on the analysis of the effects of public expenditure management at different levels of government have been developed in several directions. First, there are those that analyze on the side of government efficiency from practical applications, which consider only certain types of public spending. Then there are those studies that analyze the efficiency of government in quantitative terms, using information on inputs (imputs) of government spending, but not of impact.

Programs like, Pension 65 goes beyond the economic security that seeks to contribute to the improvement of the welfare of its users. Therefore, coordinated actions are established with the Ministry of Health and the Integral Health System (SIS) so that users are automatically insured and can access quality health services. This represents a significant step forward in the recovery of their rights within the framework of the State's social inclusion policy. It also promoted the improvement of the quality of life of the elderly, from the revaluation of their social image and their role as bearers of customs and traditions that reinforce the collective memory and local identity, constituting a value for their communities [1].

Recent studies find that JUNTOS - Conditional Cash Transfer Program - has generated significant positive results in several of its areas of intervention, but the magnitude of these effects is still small and in some cases the expected results are not yet achieved. The studies indicate several obstacles that could be preventing the program from achieving its objectives, among which it is worth highlighting information problems, inefficient implementation of mechanisms to verify compliance with conditions and process problems, among others. In addition to these difficulties, gaps in the supply of services in the places where 
JUNTOS operates can be key to explaining the low or null impact of the program on some variables.

According to data from the INEI [2] [3] [4] nationwide, 63 thousand 474 committees of the "Glass of Milk Program" have been registered, which attended a total of 2 million 452 thousand 226 people. Of this total, $28.6 \%$ is located in the province of Lima and the rest is distributed in the departments of Cajamarca (7.0\%), Piura (6.1\%), Loreto (5.1\%), Puno. (4.7\%), among the main ones. According to district, the largest number of beneficiaries is in the districts of Comas (116 thousand 992), San Juan de Lurigancho (85 thousand 369), Villa El Salvador (62 thousand 369) and Villa Maria del Triunfo (56 thousand 916); all located in the province of Lima. According to [5], it indicates that the recent literature that analyzes the impact of non-conditional transfer programs to the Elderly (AM) in the labor market focuses not only on the trade-off between employment (hours employed at work) and leisure, but also in the change in the labor supply according to gender and according to the characteristics of the labor market under analysis [5] [6].

Various empirical investigations at the international level have found evidence of some type of negative effect of a non-contributory pension on the labor supply of the beneficiaries. In the case of Mexico, the program "70 and over" is aimed at adults over 70 who live in rural areas. The evaluations show a fall in the number of seniors working in paid jobs but that is compensated by an increase in those who work in family businesses without remuneration informally. In this way, the proportion of beneficiaries who are working was reduced by $18 \%$ as a result of being a beneficiary of the program. In addition, the hours allocated to work for payment are reduced by $37 \%$ and are replaced by hours in unpaid family work [7]. Likewise, it was proved that the program generated greater social welfare even for the elderly who did not they had a negative effect on their labor supply [1], cited by [8].

According to [5], he investigates the impact of the Brazilian CCT program, the Bolsa Família Program (PBF), on the decision of the beneficiaries to offer themselves as labor. The theoretical starting point is the following: households have a strategy of distributing time between domestic tasks and paid work. Disturbances in income, such as monetary transfers, modify these preferences in terms of time distribution. Using data from the annual household survey of Brazil - PNAD-2006, [9] conducted an empirical analysis to determine if the above-mentioned effects are true or not. The PBF program focuses on two groups of families. The first includes poor families whose monthly income per capita was between $\mathrm{R} \$ 50.00$ and $\mathrm{R} \$ 100.00$ in 2006 . This group received variable transfers of $\mathrm{R} \$ 15.00$ per child or nursing mother, up to maximum of three people. The second group includes families located below the extreme poverty line whose monthly income per capita was less than $\mathrm{R} \$ 50.00$. In addition to variable transfers, this second group received a fixed transfer of $\mathrm{R}$ $\$ 50.00$. This is consistent with Becker's Theory of Time Distribution, cited by 
[5], which suggests that there is a substitution between paid work hours and the time assigned to domestic chores [10].

Impact evaluation is a type of summative evaluation. The World Bank defines impact assessment as the measurement of changes in the well-being of individuals that can be attributed to a specific program or policy [11]. Its general purpose is to determine the effectiveness of policies, programs or projects executed [12]. Like other summative evaluation techniques, impact evaluation can be used to determine the extent to which planned results were produced or achieved, as well as to improve other projects or programs in execution or future [1].

The role of the impact evaluation, like any other evaluation, can be done before (ex ante) or after (ex-post) of the execution of the project. The ex-ante evaluation is located between the stages of formulation in the project cycle (definition of objectives and design of products) and the analysis of costs and benefits. What allows to make adjustments to the design of the project in function of the formulated objectives, and forward complements the analysis of costs and benefits, by means of the construction of indicators of cost per unit of impact. Providing additional information in the investment decision. On the other hand, the ex-post impact evaluation is located at the end of the project operation, determining if there were changes in the target population, its magnitude, and which segment of the population benefited, among others [13] [14] [15] [16].

$$
a=Y_{1 i}-Y_{0 i}
$$

where $Y_{1 i}$ are the conditions of change that the target population reached when it participated in the Program, $Y_{0 i}$ represents the conditions of change that the target population would have reached in the absence of the Program and ai is the impact of the Program on the Target Population i, the impact never it can be observed directly, since only one of the two potential situations (participating or not participating) is observed for each context at a given time [17]. Thus, the impact evaluation can observe $Y_{1 i}$ for all beneficiaries of the Program, and the problem that must be solved is the estimation of $Y_{01}$, which is commonly called the counterfactual scenario, [9] [15] [16].

Establish that the poverty reduction strategy in Latin America in recent decades has been concentrated in five types of programs: food subsidies, cash transfers, temporary employment, investment in infrastructure and self-employment [7]. Since the 1990s, a large number of these initiatives have been part of social protection networks created in Latin American countries, with the aim of integrating a series of interventions aimed at creating and strengthening the human capital of the population. In general, these social protection programs are actions that seek to reduce the vulnerability of households to negative events such as an economic recession, natural disasters, the death or illness of some of the members of the household, etc. The target population of these types of interventions are those households that are below or close to the poverty line.

Coverage. This is the existing ratio between the number of people served and 
the size of the target population.

$$
\text { Coverage }=\frac{\text { Number of people served }}{\text { Size of the target population }} \times 100
$$

When there is no difference in the beneficiary population between those that integrate (or not) the target population, gross coverage is obtained. When only the beneficiaries that are part of it are considered, there is a net coverage. The latter can reach values that fluctuate between 0 and $100 \%$; the gross coverage could exceed this limit, if the offer was larger than the target population

$$
\begin{gathered}
\text { Coverage }=\frac{\text { TTP }+ \text { NOTP }}{\text { TPP }} \times 100 \\
\text { Coverage }=\frac{\text { TTP }}{\text { TPP }} \times 100
\end{gathered}
$$

TTP $=$ Target Target Population (those who have the need and receive the products)

NOTP $=$ Non Objective Target Population (those who do not have the need but receive the products)

TPP = Target Programmed Population (the population that has the need and is the recipient of the program)

Focus. The idea of a social policy based on the targeting of spending arises from the prevailing need to allocate scarce public resources in the most effective way possible. That is, obtain the greatest impact in terms of alleviating poverty for each new sun budgeted for it. The targeted policy involves the identification of vulnerable population groups, a process typically assisted with the preparation of poverty maps and the definition of the profiles of future beneficiaries of government assistance. To this end, administrative costs must inevitably be incurred which, in practice, render the information with which the authorities implement expenditure targeting imperfectly and incompletely [13] [18].

\section{Materials and Methods}

\subsection{Materials}

- Panel data review of the "Pension 65", Juntos, QaliWarma and Vaso de Leche programs.

- Review of books, magazines, Internet, among others

- Monitoring reports and annual reports of the "Pension 65", Juntos, QaliWarma and Vaso de Leche (2012-2017) programs.

- Data base of ENAHO/INEI/ENDES (2016)

- The STATA statistical package was used.

\subsection{Method}

The method used for the evaluation of impact is Differences in Differences, this design allows us to incorporate some degree of pre-existing differences between the treatment group and the control group, controlling for observable 
characteristics of the latter [19]. In this way, two approaches were considered to estimate the impact of the program. In the first approach, we consider the population group targeted by the programs in situations of poverty and extreme poverty, which we consider as a treatment group, and as a control group the population in the same social conditions but who are beneficiaries of the programs, which would be our control group.

Double difference model (D’D).

\begin{tabular}{ccc}
\hline Characteristic & Treatment Group & Control Group \\
\hline Poor & $\begin{array}{c}\text { Population that meet admission } \\
\text { requirements for all programs. }\end{array}$ & $\begin{array}{c}\text { Population with similar } \\
\text { characteristics to the target } \\
\text { population, for all programs. }\end{array}$ \\
Extreme poor & $\begin{array}{c}\text { Population that meet admission } \\
\text { requirements for all programs. }\end{array}$ & $\begin{array}{c}\text { Population with characteristics } \\
\text { similar to the target population, } \\
\text { for all programs. }\end{array}$ \\
& $E\left[Y_{1}(1)-Y_{0}(1) \mid D=1\right]$ & \\
\hline
\end{tabular}

The units of analysis is the magnitude of the impact generated in its different components as a consequence of the implementation of the social programs "Pension 65", Juntos, Qali-warma and Vaso de leche in the Puno Region. While the observation units will be made up of the beneficiaries of the social programs "Pension 65", Juntos, Qali-warma and Vaso de Leche in the Puno Region. For the case of the study, we will use a simple random sample of each social program, taking into account the number of beneficiaries by provinces at the Region level.

$$
\frac{N *\left(\alpha_{c} * 0.5\right)^{2}}{1+\left(e^{2} *(N-1)\right)}
$$

\begin{tabular}{ccc}
\hline \multicolumn{3}{c}{ DEFINITION OF THE SAMPLE POPULATION } \\
\hline PROGRAMS IN THE PUNO REGION & Control Group & Treatment Group \\
\hline PENSIÓN 65 & 2864 & 6343 \\
JUNTOS & 3140 & 5111 \\
QALI -WARMA & 4571 & 8265 \\
VASO DE LECHE & 2090 & 2909 \\
TOTAL & $\mathbf{1 2 , 6 6 5}$ & $\mathbf{2 2 , 6 3 1}$ \\
\hline
\end{tabular}

The main source of information that has been used in the research is the $\mathrm{Na}$ tional Household Survey (ENAHO), which is prepared every year by the National Institute of Statistics and Informatics [4]. This survey is representative at the departmental level and contains information on hours worked, employment status, education, membership in social programs, housing materials, access to basic services, among others; that are necessary for the regression analysis presented. 


\section{Results and Discussions (Tables 1-8, Graphs 1-3)}

\subsection{Coverage and Targeting Mechanisms of the "Pension 65" Program in the Puno Region}

The policy dilemma in a world of limited resources and imperfect information is, therefore, to find a satisfactory balance between administrative costs and program management, as measured by targeting errors, where the authorities must decide how much each can tolerate. The main difficulty in finding a solution to this dilemma is that the measures taken to reduce one type of error usually cause an increase in the other [13] [20] [21] [22].

\section{- Coverage of emblematic social programs in the Puno region.}

In this section, we analyze some impact variables such as: coverage, targeting, efficiency and effectiveness of the social programs "Pension 65", Juntos, Qaliwarma and Vaso de Leche, implemented by the State in the Puno region. With regard to the coverage variable, social programs have the following characteristics. Within the framework of the National Strategy for Development and Social Inclusion, "Include to grow", the MIDIS [23], through the National Program of Solidarity Assistance "Pension 65", has provided until 2017 economic security to 56,849 thousand people aged 65 to more than living in conditions of extreme poverty in 109 districts, in 13 provinces of the Puno region; the Juntos program was able to pay 55,904,000 users economically during 2017; the Qaliwarma program has benefited a total of 145,903,000 thousand users among schoolchildren in 2017 and the Vaso de Leche program covered $126,983,000$ thousand people in the Puno region (see Graph 1).

Likewise, the social programs under study, although it is true that they have a relatively updated diagnosis that serves as a methodological support for measuring and updating the user population on a regular basis, which allows it to be a relevant input for short-term planning. and medium term. On the other hand, programs such as pension 65, Juntos, and Qaliwarma have developed supervisions to beneficiaries in a timely manner in the previous period; However, there is no evidence of improvements in the targeting effectiveness of the target population, which allows detecting anomalies in the allocation of resources or

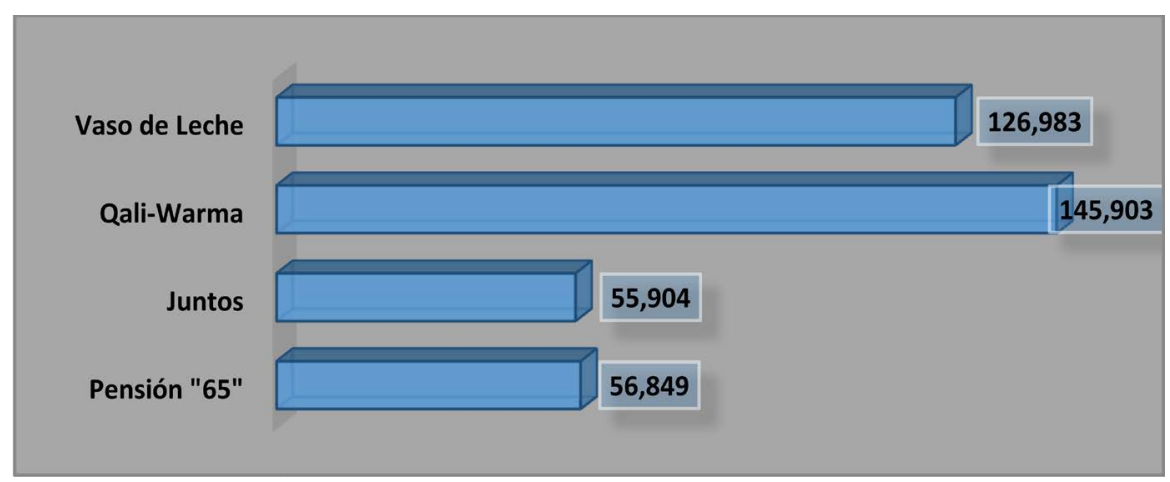

Source. Own elaboration based on data from social programs-2017.

Graph 1. Regional coverage of emblematic social programs in the Puno region-2017. 
errors in targeting (Graph 2).

Suns; followed by the Qaliwarma social program with the sum of 65,669,249 million soles; while the social program Juntos amounts the sum of $42,900,000$ new soles paid during the year 2017 through the banking system, according to a specific schedule that is coordinated for each payment operation

\section{- Problems of targeting social programs in the Puno region}

Targeting is a process by which public resources are directed towards a certain group of recipients generally selected according to the criterion of poverty. In this way, the targeting policies of social spending are aimed at prioritizing the population in extreme poverty, under the assumption that with this, spending is concentrated on the people who can benefit most from this policy and thus saves resources that they could have been assigned to those who do not require state intervention [24]. However, the intervention of a program can be subject to two types of errors: The inclusion or filtering error: This refers to the fact that the benefit of a given social program reaches people who are not part of the target group of the program and measured as the percentage of that group of beneficiaries [12]. The exclusion or undercoverage error. This refers to the gap between the target group of the program and those that effectively participate in it, and is measured as the percentage of the target population of the program that is not covered by it [25] [26].

The targeting errors are constant in the social programs in the country and mainly in the Puno region, this arises when a person who is not poor as poor could be classified, admitted to a program (infiltration or error of inclusion) or it could be classified as a poor person as not poor, denied access to the program

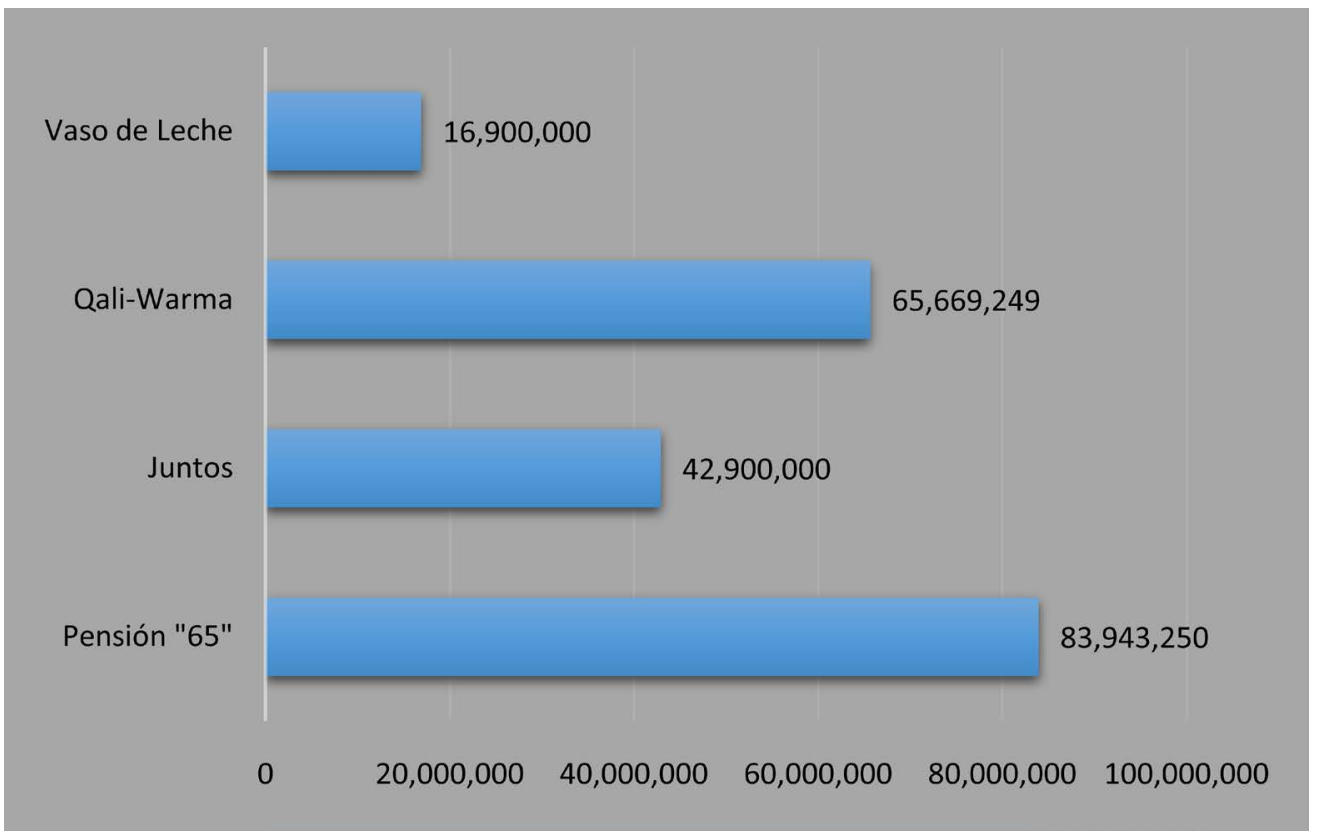

Source. Own elaboration based on data from social programs-2017.

Graph 2. Social investment expenditure, according to social programs in the Puno region-2017. (in millions of soles). 
(undercoverage or exclusion error). Both errors are undoubtedly inconvenient and reduce the effectiveness of the program [27] [28].

When measuring the undercoverage, it is clear that no social program approaches the ideal of covering $100 \%$ of the target population. When comparing the figures according to the type of poverty, it is seen that the situation worsens when considering the multidimensional poverty approach. This shows that, under the approach of the government of President Humala, there are people who are not being considered in the process of targeting poverty alleviation programs. The monetary approach contributes to this fact and must be corrected to avoid vicious cycles of intergenerational poverty [29] [30] [31]. By looking at graph \# 03, the level of undercoverage of the different social programs is evidenced, as a result of the error exclusion of users in the targeting process, that is, they are people who deserve to be in the program and are not considered. In this regard, the Juntos program registers the highest percentage in undercoverage $(20.42 \%)$; followed by the pension program 65, which registered 17.06\%; while the Vaso de Leche program 8.43\%; and the QaliWarma program reaches 7.89\% at the level of the Puno region.

On the other hand, in Graph 3, filtering levels of the user population are also observed, the Vaso de Leche program shows the highest percentage of filtration that reaches $79.84 \%$ in the region, followed by the Pension 65 program. $52.42 \%$, the Juntos program records a $49.87 \%$ leak and finally the QaliWarma program records a $38.49 \%$ leak. This phenomenon wastes program resources by allocating less to the poor or increasing the budget required to obtain the same impact on poverty reduction, while undercoverage leaves the most vulnerable without

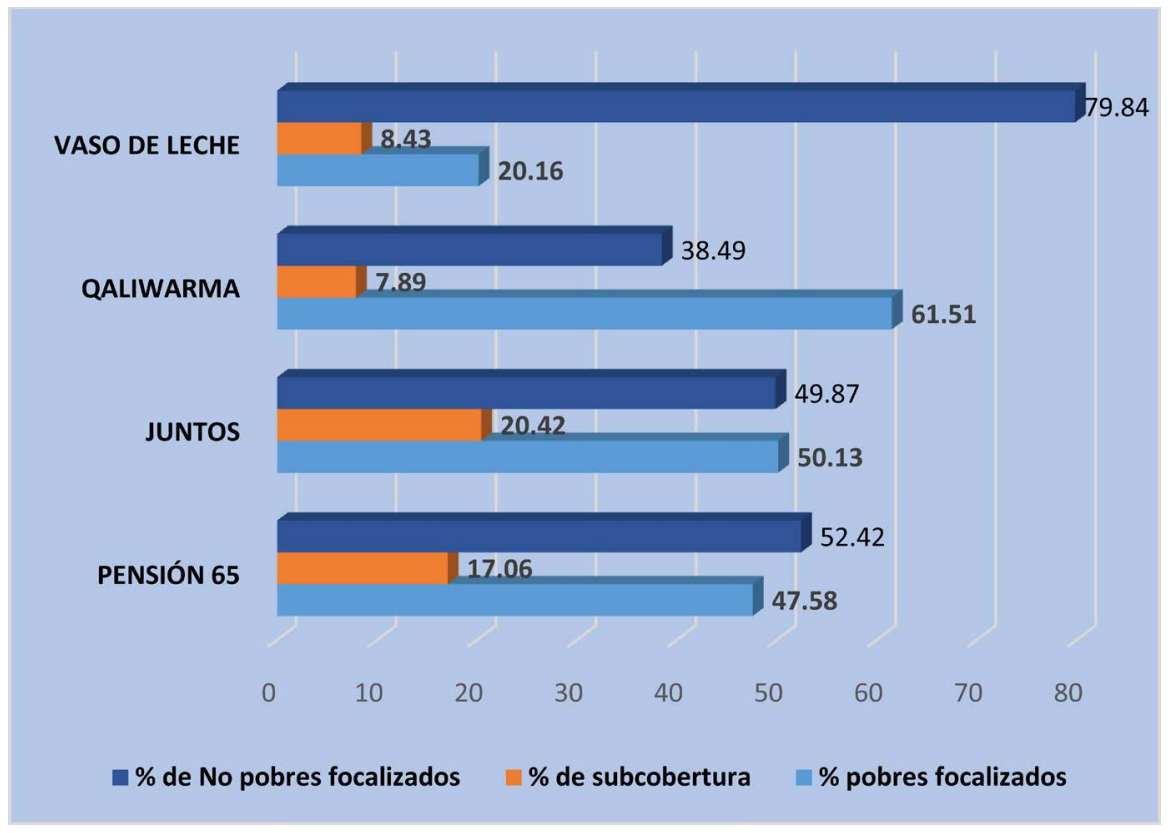

Source. Own elaboration based on data from social programs-2017.

Graph 3. Levels of undercoverage and filtration in social programs, according to the multidimensional poverty approach in the Puno region 2017. 
assistance and maintains the same social status.

\subsection{The Social Impact Expressed in the Reduction of Multidimensional Poverty of the Target Population of Social Programs in the Puno Region}

The first evaluation question to be solved with the quantitative estimate of the impact of an intervention is what would have been the situation of the beneficiaries if they had not participated in the intervention or had not been exposed to the program being evaluated. This is a question that applies to any type of intervention and its study allows analyzing the expected and unexpected effects that the intervention is generating on the beneficiaries. This idea can be represented by the following equation [13] [15].

$$
\alpha_{i}=Y_{1 i}-Y_{0 i}
$$

where $Y_{1 i}$ are the living conditions that the individual reached when he participated in the program, $Y_{0 i}$ represents the living conditions that the individual would have achieved in the absence of the program, and $\langle i$ is the impact of the program on the person $i$. The impact can never be directly observed, since only one of the two potential situations (participating or not participating) is observed for each individual at a given time [17]. Thus, the impact evaluation will only have $Y_{1 i}$ observations for the beneficiaries of the program, and the problem that must be solved is the $Y_{0 i}$ estimate, which is commonly called the counterfactual scenario.

EFFECTS IDENTIFIED FROM THE OBJECTIVES OF THE PROGRAMS

Effect 1: Increase in household income.

Effect 2: Increase in health care.

Effect 3: Increase in health expenses.

Effect 4: Increase in school enrollment.

Affect 5: Increase in school attendance rate

Effect 5: Increase in school performance

Effect 6: Increase in food expenses

Effect 7: Decrease in work days

\section{- Measuring the impact of social programs in the Puno region.}

To understand in more detail the effects of the programs (Pension 65, Together, QaliWarma and Vaso de Leche) depending on the number of beneficiaries receiving the benefits, let's think of a household in which there are more than two beneficiaries who receive a program. Within poor households, for the case of Pension 65, the elderly poor would only work if the total income of the household was not enough to guarantee minimum living conditions [32]. If within the same home, there are two people who receive the transfer of Pension 65, increasing the income of the household much more than in the case of a household with only one beneficiary, these people will have an incentive to stop working and dedicate themselves to domestic chores, care of the children of the home or other unpaid activities [9] [33]. 
The "Pension 65 and Together" programs, in their analyzes, assume that older adults work to increase their income, because they have no other means of survival. In the case of Juntos, the beneficiaries increase their income and expenses in education and health. While in the food programs such as "QaliWarma and Vaso de Leche" users are expected to increase food expenses and ensure the school continuity of their children. The objective of evaluation techniques is to measure the impact of a (political) treatment on a population. The intention is to know if the treated population is better than it would be if it had not been treated. In this part we will study the problem of estimating average effects of treatment (ATE). This is a special case of an average partial effect referred to a binary explanatory variable. These binary indicators originally arose from medical treatments, but can be applied to problems where the explanatory variable is binary [34].

\section{- Average effect of treatment on treated patients (TT)}

Another commonly used measure is the "average effect of treatment on the treated" (Average Treatment Effect on the Treated-TT) which is calculated as follows:

$$
\mathrm{TT}=E\left(y_{1}-y_{0} / w=1\right)
$$

This measure is defined as the average effect for those who actually participate in the program. In some cases TT and ATE are equivalent but in general they differ. On the other hand TT can be estimated under the less strong assumption of independence between $W$ and $Y_{1}$, so:

$E(Y / w=1)-E(Y / w=0)=E\left(Y_{0} / w=1\right)+E\left(Y_{1}-Y_{0} / w=1\right)-E\left(Y_{0} / w=0\right) \quad$, when reordering:

$$
=\underbrace{E\left(Y_{0} / w=1\right)-E\left(Y_{0} / w=0\right)}_{\text {impact of the participant, given that he participated }}+\underbrace{E\left(Y_{1}-Y_{0} / w=1\right)}
$$

if the previous assumption involving $E\left(Y_{0} / w\right)=E\left(Y_{0}\right)$ is fulfilled, then the term contained in the key disappears, so the difference in means is a consistent estimator of TT. First we obtain the simplest estimate, that of ATE assuming that $w$ is independent of $Y_{1}$ and $Y_{0}$. That is, the case in which there is pure randomization. So $\mathrm{ATE}=E\left(Y_{1}-Y_{0}\right)$. To formalize this framework, denote $\mathrm{C}$ as the control group and $\mathrm{T}$ as the treatment group: The dichotomous variable DT takes the value of 1 for those individuals belonging to the control group and the value of 0 for those individuals who are in the control group [35] [36]. Control group. Denote as $D 2$ the dichotomous variable of the second period (change after the policy). Schematically we have:

$$
D T=\left\{\begin{array}{ll}
1 & \text { if it is treated } \\
0 & \text { if it is control }
\end{array}, \quad D 2= \begin{cases}1 & \text { after } \\
0 & \text { before }\end{cases}\right.
$$

So the simplest equation to express the change in the "Pension 65 " program is:

$$
Y=\beta_{0}+\delta_{0} D 2+\beta_{1} D T+\delta_{1} D 2-D T+\mu
$$

where $y$ is the result variable of interest, $D 2 D T$ is equal to 1 for those 
individuals in the treatment group in the second year and $D 2$ captures aggregate factors that affect and over time in the same way to both treated and controls. This model implies the following:

$$
\begin{gathered}
E(y / D 2=0, D T=0)=\beta_{0} \\
E(y / D 2=1, D T=0)=\beta_{0}+\delta_{0} \\
E(y / D 2=0, D T=1)=\beta_{0}+\beta_{1} \\
E(y / D 2=1, D T=1)=\beta_{0}+\beta_{1}+\delta_{0}+\delta_{1}
\end{gathered}
$$

Based on this, the meaning of each estimated parameter is identified, in such a way that:

1) $\sigma_{0}=E(Y / D 2=1, D T=0)-E(Y / D 2=0, D T=0)$ Capture the difference between the untreated as to how they were before and after treatment.

2) $\beta_{1}=E(Y / D 2=0, D T=1)-E(Y / D 2=0, D T=0)$ Capture possible differences between treated individuals and control individuals before the change in policy occurred. If $\beta_{1}=0$ the selection is random.

3) $\sigma_{0}+\sigma_{1}=E(Y / D 2=1, D T=1)-E(Y / D 2=0, D T=1)$ Capture the difference between those treated after treatment.

4) $\beta_{1}+\sigma_{0}+\sigma_{1}=E(Y / D 2=1, D T=1)-E(Y / D 2=0, D T=0)$ Capture the difference between those treated after treatment and those not treated before treatment.

The previous estimators are interesting but the estimator of $\delta_{1}$ constitutes the central and most interesting point of the regression. Define $\bar{y}_{c, 1}$ as the sample mean of and for the control group in the first year; and either $\bar{y}_{c .2}$ and the sample mean for the control group in the second year. So $\hat{\delta}_{1}$ It can be expressed as:

$$
\hat{\delta}_{1}=\left(\bar{y}_{T, 2}-\bar{y}_{T, 1}\right)-\left(\bar{y}_{c, 2}-\bar{y}_{c, 1}\right)
$$

Which is called as a difference-in-difference estimator (DID) which captures the effect attributable to the treatment. However, for the estimator to have no bias, it is still necessary that the change in the program is not systematically related to other factors that affect and, therefore, that are hidden in $u$. With the database that we have, with which we will analyze the impact of the programs "Pension 65", Together, Qaliwarma and Vaso de Leche in the period 2012 - 2017 in the components of income, health care, food expenses the treated and untreated population. So what we need is to know:

$Y_{c 1}$. The average impact on the variables of the control group before treatment.

$Y_{c 2}$. The average impact on the variables of the control group after treatment.

$Y_{t 1}$. Average impact on the variables of the treatment group before the program.

$Y_{t 2}$. Average impact on the variables of the treatment group after the program.

The Difference in Difference (DD) test for the case of the Pension 65 program, the values are adjusted much more than with the pre-posttest applied above; that 
is, it is possible to maintain that the increase in monthly income of 55.32 soles is due to the intervention of the program. In the same way it can be observed with the other variables considered in the model, the variable "work days" with the DD estimator experiences a decrease of 6.7 days per month, that result is the result of participation in the program. Regarding health care for users of the program, a positive impact with this method is also evident. A preliminary step to the estimations is to try to observe how the control and treatment groups have behaved before the program becomes operational. That is, we can affirm that the elderly poor who receive treatment are significantly different from those poor older adults who do not receive it (see Table 1 ).

From these results, there is a positive relationship between the variables (monthly income and participation in the program) where, for each increase in participation in the program, an increase of approximately 99.62 soles per month is observed. This regression coefficient is statistically significant at all conventional levels $(F=0.000)$. On the other hand, the coefficient of determination indicates that around $29.0 \%$ of the variation in monthly income is explained by participating in the Pension 65 program. "The effect of "Pension 65" on the monthly income of the elderly (which is equivalent to being an adult over 65 years of age in this specification) is significant at $95 \%$ confidence. This effect

Table 1. Impact of the Pension 65 program on the reduction of multidimensional poverty with the Difference in Difference (DD) model.

\begin{tabular}{|c|c|c|c|c|c|c|}
\hline Condition & Variables & Observ. & $\begin{array}{l}\text { Average achieved } \\
\text { (2017) }\end{array}$ & $\begin{array}{l}\text { Average achieved } \\
\quad(2013)\end{array}$ & $\begin{array}{l}\text { Difference } \\
E\left(Y_{1}-Y_{0}\right)\end{array}$ & $\begin{array}{c}\text { Difference in Difference } \\
E\left(Y_{1 t}-Y_{0 t}\right)-\left(Y_{1 c}-Y_{0 c}\right)\end{array}$ \\
\hline G. Treatment & \multirow[b]{2}{*}{ Monthly income } & 6343 & 232.9103 & 170.8182 & 62.0921 & \multirow[b]{2}{*}{55.3183} \\
\hline G. Control & & 2864 & 129.8534 & 123.0796 & 6.7738 & \\
\hline G. Treatment & \multirow{2}{*}{ Housing condition } & 6343 & 1.795993 & 1.32000 & 0.475993 & \multirow{2}{*}{0.376789} \\
\hline G. Control & & 2864 & 1.244204 & 1.14500 & 0.099204 & \\
\hline G. Treatment & \multirow{2}{*}{ Annual savingsl } & 6343 & 264.9062 & 156.9131 & 107.9931 & \multirow{2}{*}{93.41559} \\
\hline G. Control & & 2864 & 78.94553 & 64.36802 & 14.57751 & \\
\hline G. Treatment & \multirow{2}{*}{ Workdays } & 6343 & 12.11635 & 20.08545 & -7.9691 & \multirow{2}{*}{-6.78334} \\
\hline G. Control & & 2864 & 23.3963 & 22.21054 & 1.18576 & \\
\hline G. Treatment & \multirow{2}{*}{$\begin{array}{l}\text { Visits to the } \\
\text { doctor }\end{array}$} & 6343 & 2.169793 & 1.166798 & 1.002995 & \multirow{2}{*}{0.7327436} \\
\hline G. Control & & 2864 & 0.3219274 & 0.051676 & 0.2702514 & \\
\hline G. Treatment & \multirow[b]{2}{*}{ Health care } & 6343 & 0.7313574 & 0.3170424 & 0.414315 & \multirow[b]{2}{*}{0.2802368} \\
\hline G. Control & & 2864 & 0.2248603 & 0.0907821 & 0.1340782 & \\
\hline G. Treatment & \multirow[b]{2}{*}{ Economic security } & 6343 & 0.9823427 & 0.8527511 & 0.1295916 & \multirow[b]{2}{*}{0.0981671} \\
\hline G. Control & & 2864 & 0.1421089 & 0.1106844 & 0.0314245 & \\
\hline G. Treatment & \multirow{2}{*}{ Autonomy } & 6343 & 0.6588365 & 0.4012297 & 0.2576068 & \multirow{2}{*}{0.2087241} \\
\hline G. Control & & 2864 & 0.5101257 & 0.461243 & 0.0488827 & \\
\hline
\end{tabular}

Source. Own preparation based on the available data base of the 2017 program. 
Table 2. Pension 65. Regression xi: monthly income 2017, i.program, annual savings 2017, account with SIS 2017, working days 2017, autonomous 2017 .

\begin{tabular}{|c|c|c|c|c|c|c|c|c|c|}
\hline \multirow{2}{*}{$\begin{array}{c}\text { i.programa } \\
\text { Scurce }\end{array}$} & \multicolumn{2}{|c|}{-Iprograma_0-2 } & \multirow[b]{2}{*}{ MS } & \multicolumn{4}{|c|}{ (naturally coded;_Iprograma-0 omitted) } & & \\
\hline & SS & $\mathrm{df}$ & & & $\begin{array}{c}\text { Number of } \\
\text { obs. }\end{array}$ & $=$ & 9207 & & \\
\hline & & & & & $\mathrm{F}(5,9201)$ & $=$ & 745.23 & & \\
\hline Model & $21,004,444.9$ & 5 & $4,200,888.97$ & & Prob $>$ F & $=$ & 0.0000 & & \\
\hline \multirow[t]{2}{*}{ Residual } & $51,866,362.1$ & 9201 & 5637.03534 & \multicolumn{4}{|c|}{ R-squared } & & \\
\hline & & & & & Adj R-squared & $\begin{array}{l}= \\
=\end{array}$ & $\begin{array}{l}0.2882 \\
0.2879\end{array}$ & & \\
\hline \multirow[t]{4}{*}{ Total } & $72,870,807$ & 9206 & 7915.57756 & & Root MSE & $=$ & 75.08 & & \\
\hline & \multicolumn{2}{|c|}{ home income 2017} & & Coef. & Std. Err. & $\mathrm{t}$ & $\mathrm{P}>/ \mathrm{t} /$ & (95\% Conf. & Interval 1) \\
\hline & \multicolumn{2}{|c|}{ _I program 1} & & 99.62965 & 2.155668 & 46.22 & 0.000 & 95.40406 & 103.8552 \\
\hline & \multicolumn{3}{|c|}{ Annual savings 2017} & 0.0066795 & 0.0046197 & 1.45 & 0.148 & -0.0023761 & 0.0157352 \\
\hline \multicolumn{4}{|c|}{ Has Comprehensive Health Insurance } & 0.1207461 & 0.4153177 & 0.29 & 0.771 & -0.6933687 & 0.934861 \\
\hline \multicolumn{4}{|c|}{ Days of work 2017} & -0.1573447 & 0.0919209 & -1.71 & 0.087 & -0.3375301 & 0.0228407 \\
\hline \multicolumn{4}{|c|}{ Economic autonomy } & 2.675898 & 1.634357 & 1.64 & 0.102 & -0.5278043 & 5.879601 \\
\hline \multicolumn{4}{|c|}{ Cons } & 131.6252 & 2.802146 & 46.97 & 0.000 & 126.1324 & 137.118 \\
\hline
\end{tabular}

Source. Own preparation based on the available data base of the 2017 program.

does not seem to be different for men and women. Then, receiving "Pension 65" increases the income in the home by 99.63 soles. However, the effect of interest in this specification is that associated with the interaction between receiving Pension 65 and being poor. In this way, the effect of being a beneficiary of Pensión 65 and being poor with respect to being a beneficiary and being not poor, implies a lower number of work days in the main occupation. In other words, there are notable differences in the effect of the program on income among the poor and non-poor older adults.

Finally, we obtain the double difference estimator, which indicates the average impact of the program on the evaluation variables considered in the model, for the treatment and control group (2012-2017). As can be seen in Table 3, the difference-in-difference method yields positive values in all the variables adjusted to the model, with the exception of the school repetition variable, which shows a significant reduction in the treaties, which means that children and adolescents no longer repeat the year when they participate in the program. The explanatory variable participate or not in the program has a significant impact of 139.49 soles the increase in monthly income in the treatment group and school enrollment increases by $48.21 \%$, as well as school attendance increases by $44.64 \%$. As a result of the results it is possible to mention that the groups committed to the success of the program tend to arrogate successes and externalize the failures. The population and citizens use an opposite mechanism, impute successes to external causes and failures to the program itself. 
Table 3. Impact of the "juntos" program on the reduction of multidimensional poverty with model difference in difference (DD).

\begin{tabular}{|c|c|c|c|c|c|c|}
\hline Condition & Variables & Observ. & $\begin{array}{l}\text { Average achieved } \\
\text { (2017) }\end{array}$ & $\begin{array}{l}\text { Average achieved } \\
\text { (2013) }\end{array}$ & $\begin{array}{l}\text { Difference } \\
E\left(Y_{1}-Y_{0}\right)\end{array}$ & $\begin{array}{c}\text { Difference in Difference } \\
E\left(Y_{1 t}-Y_{0 t}\right)-\left(Y_{1 c}-Y_{0 c}\right)\end{array}$ \\
\hline G. Treatment & \multirow{2}{*}{ Monthly income 1} & 5111 & 738.6886 & 232.9779 & 505.7107 & \multirow{2}{*}{139.49} \\
\hline G. Control & & 3140 & 598.9735 & 232.7548 & 366.2187 & \\
\hline G. Treatment & \multirow{2}{*}{ Housing condition } & 5111 & 1.675993 & 1.00000 & 0.675993 & \multirow{2}{*}{0.350197} \\
\hline G. Control & & 3140 & 1.124204 & 1.00000 & 0.325796 & \\
\hline G. Treatment & \multirow{2}{*}{ Services and sanitation } & 5111 & 0.4279006 & 0.1528077 & 0.2750929 & \multirow{2}{*}{0.1499337} \\
\hline G. Control & & 3140 & 0.2732484 & 0.1480892 & 0.1251592 & \\
\hline G. Treatment & \multirow{2}{*}{$\begin{array}{c}\text { Attentions and controls } \\
\text { CRED }\end{array}$} & 5111 & 5.639405 & 0.8397574 & 4.7996476 & \multirow{2}{*}{4.5741699} \\
\hline G. Control & & 3140 & 2.052229 & 1.055096 & 0.2254777 & \\
\hline G. Treatment & \multirow{2}{*}{ Visits to the doctor } & 5111 & 5.87595 & 0.7000587 & 5.1758953 & \multirow{2}{*}{3.5446853} \\
\hline G. Control & & 3140 & 2.686306 & 1.055096 & 1.63121 & \\
\hline G. Treatment & \multirow{2}{*}{ Health care } & 5111 & 4.224027 & 0.7161025 & 3.5079245 & \multirow{2}{*}{2.5107915} \\
\hline G. Control & & 3140 & 2.052229 & 1.455096 & 0.997133 & \\
\hline G. Treatment & \multirow{2}{*}{ School repetition } & 5111 & 0.1813735 & 2.396009 & -2.2146355 & \multirow{2}{*}{-1.5130435} \\
\hline G. Control & & 3140 & 0.716879 & 1.418471 & 0.701592 & \\
\hline G. Treatment & \multirow{2}{*}{$\begin{array}{c}\text { School } \\
\text { assistance }\end{array}$} & 5111 & 0.8663667 & 0.387791 & 0.4785757 & \multirow{2}{*}{0.4464101} \\
\hline G. Control & & 3140 & 0.411465 & 0.3792994 & 0.0321656 & \\
\hline G. Treatment & \multirow{2}{*}{ School enrollment } & 5111 & 0.8757582 & 0.3870084 & 0.4887498 & \multirow{2}{*}{0.4820619} \\
\hline G. Control & & 3140 & 0.389172 & 0.3824841 & 0.0066879 & \\
\hline
\end{tabular}

Source. Own preparation based on the available data base of the 2017 program.

Table 4. P. Together xi: regression: admission to the home 2017, with program, visits to the doctor 2017, school enrollment 2017, school repetition 2017, school repetition 2012.

\begin{tabular}{|c|c|c|c|c|c|c|c|c|c|}
\hline i.programa & \multicolumn{3}{|c|}{-Iprograma_0 - 2} & \multicolumn{4}{|c|}{ (naturally coded;_Iprograma-0 omitted) } & & \\
\hline Scurce & SS & df & MS & & Number of obs. & & 8255 & & \\
\hline & & & & & $F(6,8248)$ & $=$ & 416.97 & & \\
\hline Model & $39,821,512.8$ & 6 & $6,636,918.81$ & & Prob $>$ F & $=$ & 0.0000 & & \\
\hline \multirow[t]{3}{*}{ Residual } & $131,283,107$ & 8248 & $15,916.9626$ & \multicolumn{4}{|c|}{ R-squared } & & \\
\hline & & & & \multirow{2}{*}{\multicolumn{2}{|c|}{ Adj R-squared }} & $=$ & 0.2327 & & \\
\hline & & & & & & $=$ & 0.2322 & & \\
\hline \multirow[t]{9}{*}{ Total } & $171,104,620$ & 8254 & $20,729.9031$ & & Root MSE & $=$ & 126.16 & & \\
\hline & \multicolumn{2}{|c|}{ home income 2017} & & Coef. & Std. Err. & $\mathrm{t}$ & $\mathrm{P}>/ \mathrm{t} /$ & (95\% Conf. & Interval1) \\
\hline & \multicolumn{2}{|c|}{ _I program 1} & & 92.21464 & 7.124334 & 12.94 & 0.000 & 78.24916 & 106.1801 \\
\hline & \multicolumn{2}{|c|}{ _I program 2} & & -1.227789 & 63.12887 & -0.02 & 0.984 & -124.9763 & 122.5207 \\
\hline & \multicolumn{2}{|c|}{ Visits to the doctor 2017} & & 9.046091 & 2.013904 & 4.49 & 0.000 & 5.098332 & 12.99385 \\
\hline & \multicolumn{2}{|c|}{ School enrollment 2017} & & 24.45894 & 3.491788 & 7.00 & 0.000 & 17.61416 & 31.30372 \\
\hline & \multicolumn{2}{|c|}{ Times that repeated 2017} & & -12.48107 & 2.51438 & -4.96 & 0.000 & -17.40989 & -7.552252 \\
\hline & \multicolumn{2}{|c|}{ Times that repeated 2012} & & -5.212189 & 1.628115 & -3.20 & 0.000 & -8.403704 & -2.020675 \\
\hline & \multicolumn{2}{|c|}{ _Cons } & & 591.9193 & 8.340694 & 70.97 & 0.000 & 575.5695 & 608.2692 \\
\hline
\end{tabular}

Source. Own preparation based on the available data base of the 2017 program. 
So the $\mathrm{TT}=92.21$, which means that it is estimated that the impact of the program in those who participate (treated) is to increase the household income by 92.21 soles per month, adjusting the other variables to the model. The regression coefficient is statistically significant at all conventional levels $(\mathrm{F}=$ 0.000). On the other hand, the coefficient of determination indicates that around $23.27 \%$ of household income is explained by participating in the Juntos program. Applying the difference-in-difference method must take into account the data structure that is useful for a variety of purposes, such as policy analysis, so-called data stacked in cross-section over time (PCST). The idea is that during each year a random sample of the relevant population is taken. Given that the distributions of variables tend to change over time, the assumption of identical distribution is not valid, but the assumption of independence if it can be. This gives rise to what are called independent observations but not identically distributed (inid). It is important not to confuse this independent cross section structure with a data structure such as data in the form of a panel [37].

The double difference estimator indicates that the average impact of the "Qaliwarma" program on the variables: monthly income, food expenses and permanence of children at school is positive in the period 2012-2017. That is, the users of the program now feel some increase in their income $(31.64 \%)$ for the benefits received by the program for families living in poverty and extreme poverty in the Puno region. On the other hand, QaliWarma user families have decreased by -5.4641 points in expenses related to food, which suggests that now families spend less than they spent before participating in the program and in terms of the permanence of Children and adolescents who use the program increased by $11.35 \%$. One of the evaluation objectives is, is if Qaliwarma has any effect on the educational component. For this, it is necessary to analyze, if the user is poor and meets the requirements to receive the benefits, taking into account that the program is universal in nature.

To reinforce the results of DD, the multiple linear regression model has been applied. The regression coefficient $F=0.000$ turns out to be statistically

Table 5. Impact of the QaliWarma program in the reduction of multidimensional poverty with model Difference in Difference (DD).

\begin{tabular}{ccccccc}
\hline Condition & Variables & Observ. & $\begin{array}{c}\text { Average } \\
\text { achieved } \\
(2017)\end{array}$ & $\begin{array}{c}\text { Average } \\
\text { achieved } \\
(2013)\end{array}$ & $\begin{array}{c}\text { Difference } \\
E\left(Y_{1}-Y_{0}\right)\end{array}$ & $\begin{array}{c}\text { Difference in Difference } \\
E\left(Y_{1 t}-Y_{0 t}\right)-\left(Y_{1 c}-Y_{0 c}\right)\end{array}$ \\
\hline G. Treatament & Monthly & 8265 & 784.4613 & 639.2985 & 145.1628 & \multirow{2}{*}{ income } \\
G. Control & 4571 & 732.7677 & 619.2457 & 113.522 & \\
G. Treatament & Feeding & 8265 & -67.97214 & 55.30291 & -12.66923 & -5.4641 \\
G. Control & expenses & 4571 & 74.28967 & 67.08454 & 7.20513 & \\
G. Treatament & Permanence & 8265 & 0.659615 & 0.5324131 & 0.1272019 & \multirow{2}{*}{ in school } \\
G. Control & 4571 & 0.5348239 & 0.5211131 & 0.0137108 & \\
\hline
\end{tabular}

Source. Own preparation based on the available data base of the 2017 program. 
Table 6. QaliWarma. regression: poverty index (eligible 750), household that participated in the program 1, number of hectares of land in baseline, if the boss is a woman, education of the boss complete years of education age of the head of household if survey period 0 baseline $1 \mathrm{p}==1$.

\begin{tabular}{|c|c|c|c|c|c|c|c|c|c|}
\hline \multirow{2}{*}{ Scurce } & \multirow{2}{*}{ SS } & \multirow{2}{*}{ df } & \multirow{2}{*}{ MS } & & \multicolumn{2}{|l|}{ Number of obs. } & \multicolumn{3}{|l|}{12,836} \\
\hline & & & & & $\mathrm{F}(9,4989)$ & $=$ & 1293.26 & & \\
\hline Model & $81,107,432.1$ & 5 & $16,221,486.4$ & & Prob $>$ F & $=$ & 0.0000 & & \\
\hline \multirow[t]{2}{*}{ Residual } & $160,927,795$ & 12830 & $12,543.0862$ & & \multicolumn{5}{|l|}{ R-squared } \\
\hline & & & & & Adj R-squared & $\begin{array}{l}= \\
=\end{array}$ & \multicolumn{3}{|l|}{$\begin{array}{l}0.3351 \\
0.3348\end{array}$} \\
\hline \multirow[t]{2}{*}{ Total } & $69,540,007$ & 4998 & $13,913.5669$ & & Root MSE & $=$ & 112 & & \\
\hline & \multicolumn{2}{|c|}{ Poverty index eligible 750 soles } & & Coef. & Std. Err. & $\mathrm{t}$ & $\mathrm{P}>/ \mathrm{t} /$ & (95\% Conf. & Interval 1) \\
\hline \multicolumn{4}{|c|}{ Home that participated in the program 1} & -126.398 & 2.124137 & -59.51 & 0.000 & -130.5616 & -122.2344 \\
\hline \multicolumn{4}{|c|}{ Number of hectares of land } & 4.42529 & 0.3257997 & 13.58 & 0.000 & 3.786675 & 5.063906 \\
\hline \multicolumn{4}{|c|}{ Yes, the head of the household is female } & 14.34442 & 3.421012 & 4.19 & 0.000 & 7.638725 & 21.05011 \\
\hline \multicolumn{4}{|c|}{ Complete education of the head of the household } & 9.11075 & 0.4116121 & 22.13 & 0.000 & 8.303929 & 9.917571 \\
\hline \multicolumn{4}{|c|}{ Age of the head of the household } & 2.528726 & 0.0783591 & 32.27 & 0.000 & 2.375131 & 2.682322 \\
\hline \multicolumn{4}{|c|}{ _Cons } & 622.1192 & 4.619984 & 134.66 & 0.000 & 613.0634 & 631.1751 \\
\hline
\end{tabular}

Source. Own preparation based on the available data base of the 2017 program.

Table 7. Impact of the glass of milk program in the reduction of multidimensional poverty with model difference in difference (DD).

\begin{tabular}{ccccccc}
\hline Condition & Variables & Observ. & $\begin{array}{c}\text { Average achieved } \\
(2017)\end{array}$ & $\begin{array}{c}\text { Average achieved } \\
(2013)\end{array}$ & $\begin{array}{c}\text { Difference } \\
E\left(Y_{1}-Y_{0}\right)\end{array}$ & $\begin{array}{c}\text { Difference in Difference } \\
E\left(Y_{1 t}-Y_{0 t}\right)-\left(Y_{1 c}-Y_{0 c}\right)\end{array}$ \\
\hline G. Treatament & \multirow{2}{*}{ Poverty index } & 2909 & 665.5941 & 793.8339 & -128.2398 & -74.6136 \\
G. Control & & 2090 & 740.2077 & 793.8339 & -53.6262 & -8.05311 \\
G. Treatament & & 2909 & 54.6884 & 77.53011 & -22.84171 & \\
G. Control & Feeding expenses & 2090 & 69.47745 & 54.6884 & 14.7886 & \\
\hline
\end{tabular}

Source. Own preparation based on the available data base of the 2017 program.

significant at $99 \%$ and $05 \%$ error. On the other hand, the coefficient of determination indicates that about $33.48 \%$ of the reduction of the poverty index is explained by participating in the QaliWarma program. The explanatory variable participating or not in the program has a significant impact of -126.39 reduction of poverty index in the treatment group in the region.

The double difference estimator tells us that the average impact of the "Vaso de Leche" program on the variables: poverty index, food expenditures in the period 2012-2017. That is, with these variables we will try to explain the direct effects of the program in the reduction of multidimensional poverty in the users. Given the results in Table 7, it is possible to specify that the impact of the program in reducing the poverty index is significant $(-74.6136$ points) in the benefits that the services and goods in the Puno region receive from the program. On the other hand, families using the Vaso de Leche program have decreased 
-8.05 points in expenses related to food, which suggests that families now spend less than they spent before participating in the program [36].

The regression coefficients in Table 8, represent the average changes in the response variable (permanence in the school) for a unit of change in the predictor variable (participate in the program) while keeping the other predictors constant in the model. Therefore, the regression coefficient is statistically significant for the applied regression model $(F=0.000)$, at $05 \%$ error and $0.99 \%$ significance. On the other hand, the coefficient of determination indicates that around $43.14 \%$ of the poverty index reduction is explained by participating in the Vaso de Leche program in the region. The explanatory variable participating in the program or not has a significant impact of -102.82 points of poverty reduction in the treatment group, it is through the intervention of the Vaso de Leche program in the region.

The fact of finding some significant anticipated change in the reduction of the poverty index, food expenditures of poor and extremely poor beneficiaries who meet the selection criteria, gives us evidence that the effect of being a beneficiary of the program is not unique. In this way, these effects have been divided into a pre-treatment effect and a post-treatment effect for both groups. In this part we will focus on analyzing the pre-treatment effect and the post-treatment effect

Table 8. PVL. Regression: Eligible poverty index 650, participated in the program 1, age of the head of household, age of the spouse, years of education of the head, years of education of the spouse, speaks an indigenous language, boss is a woman, home with a dirt floor, home with private bathroom.

\begin{tabular}{|c|c|c|c|c|c|c|c|c|c|}
\hline \multirow{2}{*}{ Scurce } & \multirow{2}{*}{ SS } & \multirow{2}{*}{$\mathrm{df}$} & \multirow{2}{*}{ MS } & & \multicolumn{2}{|l|}{ Number of obs. } & \multicolumn{3}{|l|}{4999} \\
\hline & & & & & $\mathrm{F}(9,4989)$ & $=$ & 422.36 & & \\
\hline Model & $300,071,916.5$ & 9 & $3,341,324.06$ & & Prob $>$ F & $=$ & 0.0000 & & \\
\hline \multirow[t]{2}{*}{ Residual } & $39,468,091.1$ & 4989 & 7911.02246 & & \multicolumn{5}{|l|}{ R-squared } \\
\hline & & & & & Adj R-squared & $\begin{array}{l}= \\
=\end{array}$ & \multicolumn{3}{|l|}{$\begin{array}{l}0.4323 \\
0.4314\end{array}$} \\
\hline \multirow[t]{2}{*}{ Total } & $69,540,007$ & 4998 & $13,913.5669$ & & Root MSE & $=$ & 88.944 & & \\
\hline & \multicolumn{3}{|c|}{ Poverty index eligible 750 soles } & Coef. & Std. Err. & $\mathrm{t}$ & $\mathrm{P}>/ \mathrm{t} /$ & (95\% Conf. & Interval 1) \\
\hline \multicolumn{4}{|c|}{ Home that participated in the program 1} & -102.8286 & 2.677937 & -38.40 & 0.000 & -108.0785 & -97.57866 \\
\hline \multicolumn{4}{|c|}{ Age of the head of household } & 1.136262 & 0.1536701 & 7.39 & 0.000 & 0.8350013 & 1.437523 \\
\hline \multicolumn{4}{|c|}{ Spouse's age } & 1.648859 & 0.1823322 & 9.04 & 0.000 & 1.291407 & 2.00631 \\
\hline \multicolumn{4}{|c|}{ Complete education of the head of the household } & 6.767834 & 0.5575847 & 12.14 & 0.000 & 5.674723 & 7.860945 \\
\hline \multicolumn{4}{|c|}{ Complete education of the spouse } & 4.446403 & 0.6242177 & 7.12 & 0.000 & 3.222662 & 5.670144 \\
\hline \multicolumn{4}{|c|}{ Yes, the boss speaks an indigenous language } & -13.39617 & 2.659079 & -504 & 0.000 & -1860913 & -8.183204 \\
\hline \multicolumn{4}{|c|}{ Yes, the head of the household is female } & 18.00727 & 4.693648 & 3.84 & 0.000 & 8.805656 & 27.20888 \\
\hline \multicolumn{4}{|c|}{ Home with dirt floor } & -5222936 & 2.732766 & -19.11 & 0.000 & -57.58679 & -46.87194 \\
\hline \multicolumn{4}{|c|}{ Home with private rooms and bathrooms } & 2.139233 & 2.620379 & 0.82 & 0.414 & -2.997863 & 7.276328 \\
\hline \multicolumn{4}{|c|}{ _Cons } & 667.379 & 7.164322 & 93.15 & 0.000 & 653.3338 & 681.4242 \\
\hline
\end{tabular}

Source. Own preparation based on the available data base of the 2017 program. 
with the double difference model.

\section{Conclusions}

Regarding the leaks of the "Pension 65" programs, Juntos, QaliWarma and Vaso de Leche, differ in percentage terms. Thus, and on the basis of the analysis carried out in this work, it is evident that problems are being experienced in an efficient allocation of social spending, especially since filtration levels have been increasing in quantitative terms in the last four years, while the undercoverage figures have remained almost at the same level in all the programs: The subcodes and filtrations represent in the following order Pension 65 (17.06\% and 52.42\%), Together (20.42\% and 49.87\%), QaliWarma (7.89\% and 38.49\%) and Glass of Milk (8.43\% and $79.84 \%)$ respectively.

The results of the double difference (DD) model show us a significant difference between the treatment group and the control group, therefore, this value is very positive in the impact of the Pension 65, Together, QaliWarma and Glass of milk, in the increase of income in the home. The value of the critical level is very small in all the tests of the variables $(F=0.000)$. With the difference-in-difference method, a positive value was obtained, that is, the average difference in monthly income between beneficiaries and non-beneficiaries in the programs is as follows: "Pension 65" (55.32) soles monthly, Together (139.49) soles per month, QaliWarma (31.64) soles per month. And while the Vaso de Leche program has had an impact on the reduction of the poverty index $(-74.61)$ in the Puno region.

Regarding health care, the results with the double difference estimator indicate the average impact of the "Pension 65" and "Juntos" programs on users and non-users of the program between 2012 and 2017. With the difference-in-difference method, a positive value was obtained, that is, the average difference in health care of the beneficiaries of "Pension 65 " receives 0.2802368 , while the beneficiaries of Juntos receive 2.5107915 more, of those that are not beneficiaries of the program.

The double difference estimator shows us that the average impact of the "Juntos" and "QaliWarma" program on the education variable is positive in the period 2012-2017. That is, the users of the mentioned programs have experienced positive results: Juntos (school enrollment increases by $48.21 \%$, as well as school attendance increases by $44.64 \%$ ); QaliWarma (the permanence of children and adolescent users of the program, has increased by $11.35 \%$ ).

The double difference estimator tells us that the average impact of the "Pension 65" program in the variable monthly work days in the period 2012-2017 is negative. In other words, users of the program (receive treatment) have reduced their workdays by -6.78334 days per month, unlike those who do not receive treatment.

Another important result is the impact on the reduction of food expenses of the beneficiaries of the QaliWarma and Vaso de Leche programs in the 
2012-2017 period, which is negative and statistically significant. That is, QaliWarma users (those receiving treatment) have reduced their food expenses by -5.46 soles per month and beneficiaries of the Vaso de Leche program have reduced their food expenses by -8.05 soles per month, in contrast to the who do not receive treatment in both programs.

Finally, given the significance of the regression tests, we can affirm that the increase in some variables (income, health care and education) and decrease in others (work days and food expenses) are statistically significant and positive in some variables and negatives in others, different from zero tells us that indeed the relationship cannot be explained by extreme values in one or another variable that may in some way affect only the means. The differences between before and after the programs are disseminated along most of the values of each of the variables studied.

\section{References}

[1] B Bosch, M. and Cuajardo, J. https://www.econstor.eu/bitstream/10419/89052/1/IDB-WP-366.pdf

[2] INEI (2013) Encuesta nacional de programas estratégicos. INEI, Lima.

[3] INEI-ENAHO (2014) Evolución de la pobreza monetaria 2009-2013 Edic. INEI, Lima.

[4] INEI-ENAHO (2015) Evolución de la pobreza monetaria Edic. INEI, Lima.

[5] Teixeira, G. (2008) Análise do impacto do Programa Bolsa Família na oferta de trabalho dos homens e mulheres. Sitio web del PNUD/CIP.

[6] Barrientos, A. (2003) What Is the Impact of Non-Contributory Pensions on Poverty? Estimates from Brazil and South Africa. Institute for Development Policy and Management, University of Manchester, Manchester. https://doi.org/10.2139/ssrn.1754420

[7] Escobal, J. and Ponce, C. (2003) The Benefits of Rural Roads: Enhancing Income Opportunities for the Rural Poor. Lima: GRADE. 52 p. Documento de trabajo, 40. http://www.grade.org.pe/publicaciones/486-the-benefits-of-rural-roads-enhancing-i ncome-opportunities-for-the-rural-poor/

[8] Torres, J. and Salinas, C. (2016) Impacto laboral potencial del acceso a Pensión 65: Un primer análisis. CIES, Lima.

[9] Schultz, T.P. (1980) Estimating Labor Supply Functions for Married Women. In: Smith, J., Ed., Female Labor Supply: Theory and Estimation, Princeton University Press, Princeton, 25-89.

[10] Barrientos, A. and Lloyd-Sherlock, P. (2002) Non-Contributory Pensions and Social Protection. Paper for the Series "Issues in Social Protection", The Social Protection Sector, International Labour Organization.

[11] Banco Mundial (2005) PovertyNet, Impact Evaluation, Overview. http://www.worldbank.org

[12] Patton, M. (2002) Qualitative Research and Evaluation Methods. 3 Edition, SAGE, New York.

[13] Cohen, E. and Franco, R. (2005) Gestión Social. Cómo lograr eficiencia e impacto en las políticas sociales. CEPAL.

[14] Guzmán, M. (2001) Evaluación de Programas e Indicadores de Desempeño. 
Transparencia y Mejoramiento de los Procedimientos para la Elaboración y Discusión Presupuestaria. Dirección de Presupuesto. Noviembre de 2001. http://www.dipres.cl

[15] Mohr, L. (1999) The Qualitative Method of Impact Analysis. American Journal of Evaluation, 20, 69-84. https://doi.org/10.1177/109821409902000106

[16] Musto, S. (1975) Análisis de eficiencia. Metodología de la evaluación de proyectos sociales de desarrollo. Madrid, Tecnos.

[17] Angrist, B. and Joshua, D. (1998) Estimating the Labor Market Impact of Voluntary Military Service using Social Security Data on Military Applicants. Econometrica, 66, 249-288. http://citeseerx.ist.psu.edu/viewdoc/download?doi=10.1.1.188.596

[18] Alfageme, A. and del Valle, M. (2009) Análisis de focalización de la política social. Serie de Documentos de Trabajo. D.T. N²009-12. Banco Central de Reserva del Perú.

[19] Bernal, R. and Peña, X. (2011) Método de Regresión Discontinua. In: Bernal, R. and Peña, X., Eds., Guía Práctica para la Evaluación de Impacto, UNIANDES, Bogotá, 189-242.

[20] Becker, G.S. (1976) The Economic Approach to Human Behaviour. University of Chicago, Chicago.

[21] Berniell, I. De la Mata, D. and Machado, M. (2014) The Impact of a Permanent Income Shock on the Situation of Women in the Household: The Case of a Pension Reform in Argentina. CEPR DP 10256.

[22] Carvalho Filho, I.E. (2012) Household Income as a Determinant of Child Labor and School Enrollment in Brazil: Evidence from a Social Secutiry Reform. Economic Development and Cultural Change, 60, 399-435. https://doi.org/10.1086/662576

[23] MIDIS (2012) Una política para el desarrollo y la inclusión social en el Perú.

[24] Rossi, P.H. (1979) Issues in the Evaluation of Human Services Delivery. In: Sechrest, L., Ed., Evaluation Studies Review Annual. Beverly Hills, Sage Publications, Thousand Oaks, Vol. 4, 69-95.

[25] Raczynski, D. (1995) Focalización de programas sociales: Lecciones de la experiencia chilena. In: Pizarro, C., Raczynski, D. and Vial, J., Eds., Políticas económicas y sociales en el Chile democrático, CIEPLAN-UNICEF, Santiago.

[26] Perrin, B. (2003) Implementing the Vision: Addressing Challenges to Results-Focused Management and Budgeting. Programa de las Naciones Unidas para el Desarrollo, PNUD, 1997. Informe de desarrollo humano.

[27] SISFOH (2010) Metodología de Cálculo del Índice de Focalización de Hogares. Ministerio de Economía y Finanzas, Dirección General de Asuntos Económicos y Sociales, Lima.

[28] Rossi, P.H., Freeman, H.E. and Wright, S.R. (1979) Evaluation. A Systematic Approach. Sage Publications, Beverly Hills.

[29] Trivelli and Tanaka, M. (2002) Las Trampas de la Focalización y la Participación. Pobreza y Políticas sociales en el Perú durante la década de Fujimori. Documento de Trabajo $\mathrm{N}^{\circ}$ 121. IEP, Lima.

[30] Vásquez, H.E. (2012) Inversión Social: Evaluación de proyectos y mediciones acotadas. Universidad del Pacífico, Lima.

[31] Vásquez, H.E. (2013) Las políticas y programas sociales del gobierno de Ollanta Humala desde la perspectiva de la pobreza multidimensional. Edic. UP-CI, Lima.

[32] Sienaret (2008) The Labour Supply Effects of the South African Sate Old Age 
Pension: Theory, Evidence and Implications. Sothern Africa Labour and Development Research Unit. Working Paper Number 20, SALDRU, University of Cape Town, Cape Town.

[33] Pensión 65, MIDIS (2013) Plan Operativo Institucional 2013. Lima.

[34] Galiani, S. and Gertler, P. (2012) Primer seguimiento a la evaluación de impacto del Programa de Atención a Adultos Mayores de 70 años y más en zonas rurales (Programa 70 y Más) SEDESOL.

[35] Aramburú, C.E. (2012) Informe Compilatorio: El Programa JUNTOS, Resultados y Retos. Presidencia de Consejo de Ministros.

[36] Cohen, E. and Franco, R. (1998) Evaluación de Proyectos Sociales. Siglo Veintiuno, México.

[37] Monge, Á. y otros (2009) Es el gasto público en programas sociales regresivo en el Perú? Centro de Investigación de la Universidad del Pacífico: Consorcio de Investigación Económica y Social, Documento de Trabajo $\mathrm{N}^{\circ} 84$, Lima. 